\title{
Investigation of engineering properties of blast furnace slag additive mortars
}

\author{
Hüseyin Boran, ${ }^{1, *}$ Osman Gunaydın, ${ }^{1}$ Kadir Gucluer $^{2}$ \\ ${ }^{1}$ Adiyaman University, Faculty of Engineering., Department of Civil Engineering, Adiyaman, Turkey, \\ huseyinboran044@gmail.com, gunaydin@adiyaman.edu.tr, ORCID: 0000-0001-5007-1788, ORCID: 0000-0001-7559-5684 \\ 2 Adiyaman University, Vocational School of Technical Sciences, Department of Construction, Adiyaman, Turkey, \\ kgucluer@adiyaman.edu.tr, ORCID: 0000-0001-7617-198X
}

\section{A B S T R A C T}

Cement, water and fine aggregate mixture is called mortar. Mortar samples suitable for the desired purpose can be obtained by adding various additives to the mortar samples. In this study, instead of standard sand, blast furnace slag (BFS) was used at $10 \%, 20 \%$ and $30 \%$ by weight in mortar samples. In order to determine the mechanical properties of the samples, compressive and flexural strength tests were applied. For the electrical resistivity values, a device with constant $30 \mathrm{~V}$ voltage was prepared and the electrical resistivity values were measured. To determine the freeze-thaw resisting properties, it was applied sodium sulfate experiment. As a result, it was seen that the best values were obtained from $30 \%$ BFS additive samples in all series. The highest resistivity values are in the sample with $30 \%$ BFS doped with 0.1856 ohm.m and $0.268 \mathrm{ohm} . \mathrm{m}$ values. The highest freeze-thaw resisting value was seen in the sample with $30 \%$ BFS with $1.35 \%$.

\section{ARTICLE INFO}

\section{Research article}

Received: 16.09 .2020

Accepted: 15.12 .2020

Keywords:

Mortar,

blast furnace slag, electrical resistivity, sodium sulphate test

${ }^{*}$ Corresponding author

\section{Introduction}

A mixture of water and cement is called cement paste. The new mixture obtained as a result of adding a fine aggregate to this mixture is called mortar. Mortars are special concretes that do not contain coarse aggregate. Currently, it is possible to gain main features according to the desired purpose by used mineral and chemical additives in production of mortar [1].

The cost of natural sand used as fine aggregate in recently developed concrete has increased the cost of construction. In this case, research has turned to studies for alternative materials that are cheap and easily accessible for natural sand [2]. To meet the global demand for concrete in the future, finding suitable alternatives to natural aggregates for preparing concrete can become a more difficult task. Therefore, the use of alternative sources for natural aggregates is becoming increasingly important. The use of granulated blast furnace slag (GBFS) aggregates in concrete by replacing natural aggregates is a promising concept because its impact strength is higher than natural aggregate. Steel slag aggregates are already used as aggregates in asphalt paved road mixes due to their mechanical strength, hardness, porosity, abrasion resistance and water absorption capacity [3].
Blast furnace slag (BFS) is a material produced by the melting of iron ore to produce iron metal [4]. The wastes as a result of the burning of limestone, coke and iron ore gangue generate BFS. The formation temperature of BFS is between 1400$1600{ }^{\circ} \mathrm{C}[5]$. The fact that BFS has a crystal structure occurs when it is slowly cooled. In this case, it can be preferred as concrete aggregate and has mechanical properties similar to basalt. On the other hand, rapid cooling is required for the formation of glassy slag [5].

It is known that blast furnace slag improves the workability of fresh concrete, extends the setting time of cement paste, affects hydration rate and perspiration reduction, and strengthens durability values in hardened concrete. Looking at the literature; It has been said that it causes a decrease in the strength gaining speed especially in the first days and an extension of the concrete setting in cold weather conditions [6].

Studies up to now show that slag additive improves concrete characteristics such as durability, permeability, corrosion resistance, workability and strength [7]. The highest electrical resistivity can be achieved with cement mortars containing high levels of BFS. With C-S-H gels reducing the water content in the cement paste as a result of the hydration of free 
$\mathrm{Ca}(\mathrm{OH})_{2}$ and pozzolanic mineral mixtures (containing $\mathrm{Al}_{2} \mathrm{O}$, $\mathrm{Fe}_{2} \mathrm{O}_{3}, \mathrm{SiO}_{2}$ etc.) and accelerates the formation of ettringitemonosulfate $[8,9]$.As a result of the reaction of BFS particles during hydration, $\mathrm{Ca}(\mathrm{OH})_{2}$ content decreases and C-S-H gels increase. Thus, it is thought that BFS grains contribute to the formation of C-S-H gels [10].

When the use of BFS as aggregate in the literature and the sulphate strengths of using BFS and pumice instead of a certain amount of aggregate in concrete pipe production; It was observed that the weight loss was the lowest in BFS and pumice added samples. While samples kept in sulphate solution for 180 days showed the best resistance of samples with $15 \%$ BFS, while the most unstable sample was the witness sample [11]. Nataraja et al.[12] investigated the use of fine aggregate GBFS in cement mortar. In this study, they changed cement mortar 1: 3 and GBFS at 0, 25, 50, 75 and 100 ratios to natural sand for a fixed $\mathrm{w} / \mathrm{c}$ ratio of $0 \%$. In the study, they looked at $100 \%$ of natural sand change with GBFS for 0.4 and $0.6 \mathrm{w} / \mathrm{c}$ ratios. Flow properties of various mixtures and their compressive strength at various ages were investigated. From this study, they observed that the GBFS could be partially used as an alternative building material for natural sand in mortar applications. They found that the reduction in flowability can be compensated for by adding an appropriate percentage of super plasticizer. Babu and Mahendran [13] investigate the physical and mechanical properties of concrete by replacing fine aggregate with BFS and GBFS. Conclusions have been drawn based on the experimental results Based on their results, it encourages the use of BFS up to $25 \%$ in concrete as a substitute for fine aggregate. The maximum compressive strength of $40.39 \mathrm{MPa}$ was obtained by replacing $25 \%$ of the fine aggregate with BFS. The use of BFS will reduce the cost of concrete by 8 to $10 \%$. Autade [14] investigated the use of steel slag in concrete instead of fine aggregate. He examined the change in the range of $0,20,40,60,80,100 \%$. He observed that the workability of concrete decreases as the percentage of substitution increases. There is a significant increase in compressive strength for $20 \%$ and $40 \%$ change; It has been stated that there is an increase of more than $20 \%$ in flexural strength and tensile strength. With regard to the strength parameters obtained at $80 \%$ and $100 \%$ substitution, it was stated as expected. $10 \%$ $20 \%$ difference in compressive strength has been observed. Seker [15] GBFS is a by-product and its use as aggregate in concrete can be an economical and environmentally friendly solution in the local area. Thus, it will become more important to find suitable alternatives for future aggregates. When the results are examined, it has shown that it has properties similar to natural aggregates and will not cause any harm if it is included in concrete.

The purpose of this study is to use these wastes in the construction sector due to the difficulties of storing byproducts that occur as a result of the use of industrial materials and damage to the environment. The selection of blast furnace slag, which is one of these by-products, as aggregate is to protect the nature, reduce the need for natural aggregate raw materials and to obtain impermeable and high quality mortar samples in terms of durability properties by using thinner materials. For this purpose, BFS additive samples were produced, compressive and flexural strength tests were made, electrical resistivity measurements were carried out and sodium sulfate test was applied.

\section{Material and method}

In this study, Portland composite cement of CEM II 42.5 type consistent with TS EN 197-1 [16] was used as a binder. Chemical components of cement and BFS used in the study are given in Table 1 . BFC's blaine fineness $2685 \mathrm{~cm}^{2} / \mathrm{gr}$.

Table 1. Chemical component of cement and BFS

\begin{tabular}{lccccccc}
\hline $\begin{array}{c}\text { Oxide } \\
(\%)\end{array}$ & $\mathrm{SiO}_{2}$ & $\mathrm{Al}_{2} \mathrm{O}_{3}$ & $\mathrm{Fe}_{2} \mathrm{O}_{3}$ & $\mathrm{CaO}$ & $\mathrm{MgO}$ & $\mathrm{K}_{2} \mathrm{O}$ & $\mathrm{Na}_{2} \mathrm{O}$ \\
\hline Cement & 19.2 & 3.88 & 4.25 & 62.8 & 3.42 & 0.34 & 2.1 \\
\hline BFS & 40.1 & 12.8 & 0.9 & 39.6 & 4.2 & 1.2 & 0.05 \\
\hline
\end{tabular}

CEN standard sand in accordance with TS EN 196-1 [17] was used in the prepared mortar mixtures. The samples have been prepared with reference to 225 gr water, 450 gr cement and 1350 gr standard sand given in TS EN 196-1 [17]. Samples were prepared by replacing $10 \%, 20 \%$ and $30 \%$ by weight BFS with standard sand. Mortar samples were prepared in a mixer and placed in molds of $40 \times 40 \times 160 \mathrm{~mm}$ using a shaking table. After the samples were kept in the mold in the laboratory for 24 hours, they were kept in the cure pool at $20 \pm 2{ }^{\circ} \mathrm{C}$ for 7,28 and 90 days experiments. The samples produced 3 pieces for each series were first subjected to the flexural strength test and the average values of the results calculated with the help of formula (1) were taken and the flexural strength values were accepted. Compressive strength test was performed on the samples obtained after flexural strength and the average of the results calculated with the help of formula (2) was accepted as the value of compressive strength.

$$
R_{f}=\frac{1.5 \times F_{f} \times 1}{b^{3}}
$$

Here; $\mathrm{R}_{\mathrm{f}}$ : Flexural strength, (Newton / mm2), b: Side length of the square section of the prism (mm), $F_{\mathrm{f}}$ : The force applied to the middle of the prism when it breaks (Newton), l: The distance between the support cylinders (mm)

$$
f_{b}=\frac{P_{k}}{A_{0}}
$$

Here; $\mathrm{f}_{\mathrm{b}}=$ Compressive strength $(\mathrm{MPa}), \mathrm{A}_{0}=$ Surface area $(\mathrm{mm} 2), \mathrm{P}_{\mathrm{k}}=$ Load at break $(\mathrm{N})$ 
For electrical resistivity measurements, the resistivity values of the samples were calculated with the help of formulas (3) and (4) by giving a constant $30 \mathrm{~V}$ voltage to the samples.

$$
\begin{gathered}
\rho=R \times \frac{S}{L} \\
R=\frac{U}{I}
\end{gathered}
$$

Here; $\rho=$ electrical resistivity $(\Omega . \mathrm{m}) ; \mathrm{R}$ is the measured resistance $(\Omega)$; L, distance between copper electrodes $(\mathrm{m}) ; \mathrm{S}$, electrode conductor area $\left(\mathrm{m}^{2}\right)$; Voltage value (volts) on $\mathrm{U}$ Electrodes; I The current intensity (amperes) passing through the sample.

For the sodium sulphate test, the solution was prepared by adding $350 \mathrm{~g}$ of sodium sulphate to 1 liter of water in accordance with ASTM C88-05 [18]. The samples were weighed as it is the state of driving oven before the experiment. The samples placed in the solution were kept between 16-18 hours. The samples removed from the solution were placed in the oven and kept in the oven at $105^{\circ} \mathrm{C}$ for about 4-6 hours until they reached their constant weight. This cycle was repeated 5 times, and as a result, the oven-dried samples were weighed. With the help of formula (5), freezing loss values were calculated. Finally, samples were subjected to compressive strength test. Compressive strength values of the samples were calculated with the help of formula (2).

$$
\frac{\left(G_{1}-G_{2}\right)}{G_{1}} \times 100
$$

$\mathrm{G}_{1}$ : The oven-dry weight of the samples before sodium sulphate the test,

$\mathrm{G}_{2}$ : The oven-dry weight of the samples after sodium sulphate the test

\section{Findings}

\subsection{Compressive and Flexural Strength Findings}

The compressive and flexural strength findings of the mortars used in 10\%, 20\% and 30\% rates from BFS are given in Fig. 1 (a) and (b).

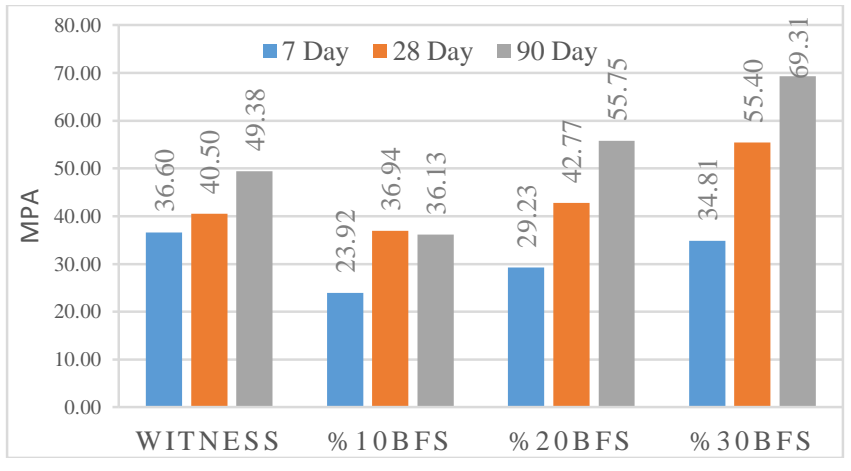

Figure 1 (a) Compressive strength findings

Looking at the compressive strength results, it was seen that the 7-day early strength was the highest with $36.6 \mathrm{MPa}$ in the witness sample. It was observed that the samples with $20 \%$ and 30\% BFS additive were higher than the witness sample at 28 and 90 days values, but the highest values were in the sample with 30\% BFS additive with $69.31 \mathrm{MPa}$. In the literature studies, it has been stated that the use of BFS reduces early strengths, but this effect largely disappears in later ages [19]. Quasrawi et al. [20], in their study, as a result of the replacement of fine aggregate and BFS, samples with BFS additives at the rate of $15-30 \%$ obtained the best results for compressive strength. The results obtained support this view. It is reported that the early age strength of slag reinforced concrete is lower than that of normal Portland cement concrete, whereas the final strength is equal or higher than the strength of normal Portland cement concrete, provided that it is cured well [21-22]. It can be said that the use of BFS as a mineral additive in certain proportions and its use as fine aggregate yields better compressive strength results compared to witness samples.

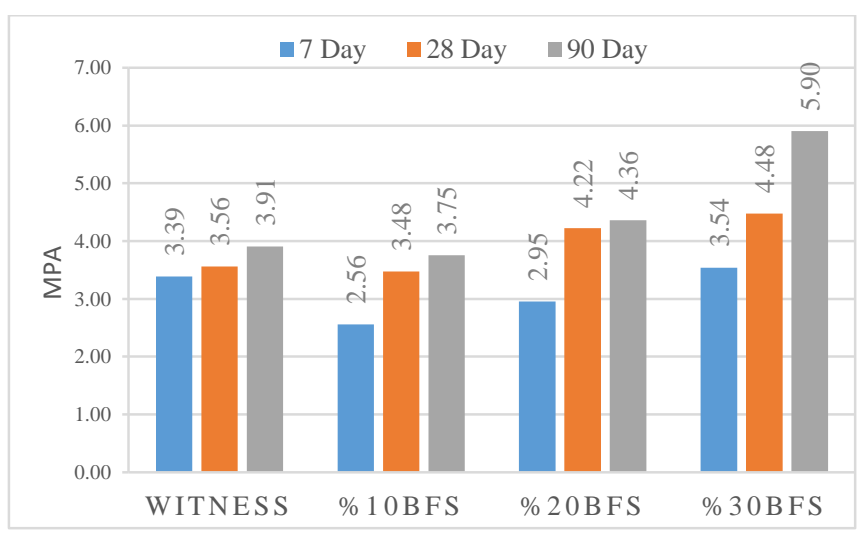

Figure 1 (b) Flexural strength findings

When the flexural strength findings were examined, it was seen that the witness sample was greater than $10 \%$ and $20 \%$ BFS added sample at 7-day early strength, but the highest value with $3.54 \mathrm{MPa}$ was found in the sample with $30 \% \mathrm{BFS}$ added. When the values of 28 and 90 days are examined, it 
was seen that the lowest values were at $3.48 \mathrm{MPa}$ and 3.75 MPa in the sample with $10 \%$ BFS and the highest values were in the sample with 4.48 MPa and 5.9 MPa with $30 \%$ BFS. When the comparison is made from the literature, Quasrawi et al. [20], in their study, as a result of the replacement of fine aggregate and BFS, samples with BFS additives at 30-50\% have obtained the best results for flexural strength The findings obtained support this view. Slag concretes with tensile strength have slightly higher tensile strength than Portland cement concrete for a given compressive strength [23]. It can be said that by using BFS as a mineral additive in certain proportions, its use as fine aggregate yields better flexural strength results compared to witness samples.

\subsection{The Electrical Resistivity Findings}

The electrical resistivity findings of the mortars used at $10 \%$, 20\% and 30\% rates from BFS are given in Fig. 2.

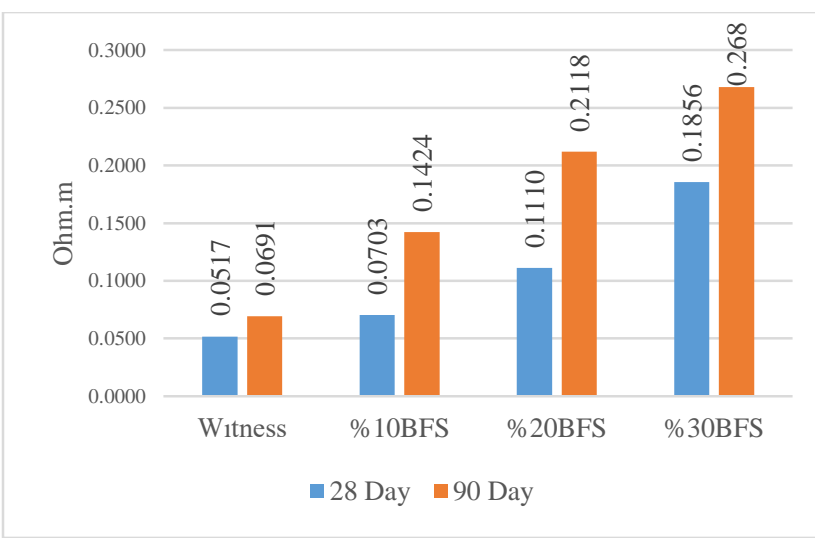

Figure 2 The electrical resistivity findings

When the electrical resistivity findings were examined, it was seen that the lowest values were in the witness sample with $0.0517 \mathrm{ohm} . \mathrm{m}$ and $0.0691 \mathrm{ohm} . \mathrm{m}$ values. The resistivity value increased with the increase in the amount of BFS. The highest values are in the sample with $30 \%$ BFS doped with 0.1856 ohm.m and 0.268 ohm.m values. Topçu et al. [10] in their study, they think that adding BFS to cement paste increases the electrical resistivity of the mixtures. Considering the values obtained above and the values obtained from this study, it can be said that preferring BFS as both mineral additive and fine aggregate gives better results than witness samples. Increasing electrical resistivity decreases electrical conductivity. As a result, it is seen that the most conductive sample is the witness sample and the least conductive one is the sample with $30 \%$ BFS doping.

\subsection{Sodium Sulphate Findings}

Findings of sodium sulphate belonging to the mortars used in $10 \%, 20 \%$ and $30 \%$ rates from BFS are given in Figure 3.

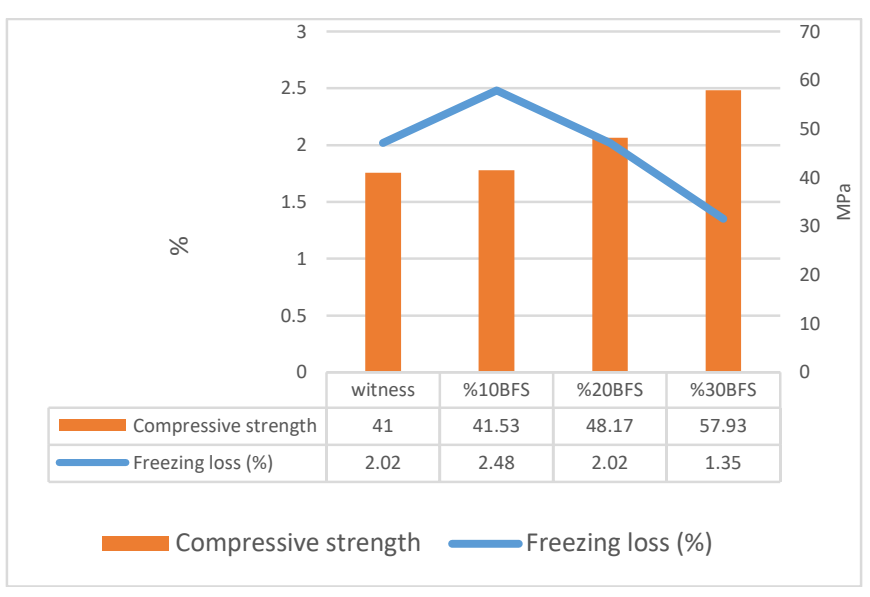

Figure 3 Sodium sulphate findings

Considering the sodium sulphate test findings, the lowest compressive strength is in the witness sample with $41 \mathrm{MPa}$. The increase in BFS positively affected the compressive strength. The highest compressive strength is $57.93 \mathrm{MPa}$ with $30 \%$ BFS added sample. The increase in the amount of BFS caused a decrease in freezing loss. As a result of, the lowest freezing loss value was seen in the sample with $30 \%$ BFS with 1.35\%. Binici et al. [20] obtained the lowest mass loss among the samples with high contribution from blast furnace slag. They also stated that blast furnace slag additive contributes positively to durability and strength. These studies confirm the results obtained above.

\section{Results}

Considering the findings obtained by adding BFS to the mortar samples instead of fine aggregate at the rates of $10 \%$, $20 \%$ and $30 \%$,

- It has been observed that increasing the amount of BFS has a positive effect on compressive strength. The fact that the witness sample has the highest value in 7-day early strength is thought to be due to the fact that mineral additives have an effect on reducing the cement setting speed.

- When looking at 7, 28 and 90 days values, it was seen that the highest flexural strength values were $3.54 \mathrm{MPa}$ at 7 days, 4.48 MPa at 28 days and $5.9 \mathrm{MPa}$ at 90 days in the sample with $30 \%$ BFS.

- The increase in the amount of BFS has also increased the electrical resistivity value. It was observed that the highest value was at 0,268 ohm.m with $30 \%$ BFS additive sample. Parallel values were obtained with the compressive strength values. Since it is known that increasing the electrical resistivity decreases the electrical conductivity, the best 
conductive witness sample is considered to be the least conductive $30 \%$ BFS additive sample.

- The increase in the amount of BFS, an increase in compressive strength has been observed under the presence of sodium sulphate. The lowest freezing loss with a value of $1.5 \%$ is in the sample with $30 \%$ BFS. In addition, it has been observed that the increase in the amount of BFS reduces the freezing loss.

- It is recommended to use the $30 \%$ BFS additive sample in mortar concrete since it is seen that the best values are obtained in terms of durability and strength.

- It can be said that the use of BFS, which is an industrial waste, in concrete or mortars at certain rates for recycling and environmental protection is not considered harmful in terms of its mechanical and durability properties.

\section{References}

[1]. Baradan B., Yazıcı H. ve Aydın S., Beton. Dokuz Eylül Üniversitesi Mühendislik Fakültesi Yayınları, İzmir: 2015.

[2]. Jadhav, P.A. ve Kulkarni, D.K., "Effect of Replacement of Natural Sand By Manufactured Sand on the Properties of Cement Mortar," International Journal of Advanced Engineering Technology, Vol. 3, No 3, (2013).

[3]. Hiraskar, K.G. ve Patil, C. "'Use of Blast Furnace Slag Aggregate in Concrete,' International Journal Of Scientific \& Engineering Research, Volume 4, Issue 5, (2013), s 95.

[4]. Thomas D., Concrete Durability. CRC Press, 2014.

[5]. Babu K. D. and Kumar V. S. R., "Efficiency of GGBS in Concrete", Cement and Concrete Research, 30, (2000), 1031- 1036.

[6]. Erdoğan T. Y., Beton. Metu Press, 5. Baskı, 2015.

[7]. Babu K. D. and Kumar V. S. R., "Efficiency of GGBS in Concrete", Cement and Concrete Research, 30, (2000), 1031- 1036.

[8]. Salem T.M., "Electrical conductivity and rheological properties of ordinary portland cement-silica fume and calcium hydroxide-silica fume pastes”, Cem Concr Res, 32, (2002), 1473-1481.

[9]. McCarter W.J., Starrs G. and Chrisp T.M., Electrical conductivity, diffusion, and permeability of portland cement-based mortars, Cem Concr Res, 30, (2000), 1395-1400.

[10]. Topçu İ. B., Uygunoğlu T. ve Hocaoğlu İ., "Yüksek fırın cüruf katkılı çimento pastalarının elektriksel özdirençlerinin araştırılması", Politeknik Dergisi, 21(2), (2018), 257-264.

[11]. Binici H. et al, “Kum Boyutunda Yüksek Fırın Cürufu ve Pomza Katkılı Beton Boruların Durabilite Özelliklerinin Araştırılması", Kahramanmaraş Sütçü İmam Üniversitesi Mühendislik Bilimleri Dergisi, 14.3, (2012), 33-44.

[12]. Nataraja, M.C., Kumar, D.P.G., Manu, A.S. ve Sanjay, M.C., ' 'Use Of Granulated Blast Furnace Slag As Fine Aggregate In Cement Mortar,’ International Jounal of Structural and Civil Engineering Research. No.2, May, (2013).

[13]. Babu, J.S. ve Mahendran, N., “Experimental Studies on Concrete Replacing Fine Aggregate with Blast Furnace Slags,' International Journal of Engineering Trends and Technology (IJETT). Volume 10, Number 8, Apr, (2014).

[14]. Autade, P. B., \& Saluja, H. S. J. S. Effect of Steel Slag as a Replacement of Fine Aggregate in M40 Grade of Concrete, 2016.

[15]. Şeker, O., “'Granüle Yüksek Fırın Cürufunun Kendiliğinden Yerleşen Beton Özelliklerine Etkisi," Master's thesis, Bartın Üniversitesi, Fen Bilimleri Enstitüsü, 2019.

[16]. Çimento-Genel Çimentolar-Bileşim, Özellikler ve Uygunluk Kriterleri, TS EN 197-1, 2002.

[17]. Çimento Deney Metotları-Dayanım Tayini, EN 196-1, 2002.

[18]. Standard Test Method for Soundness of Aggregates by Use of Sodium Sulfate or Magnesium Sulfate, ASTM C88-05, 2005.

[19]. Yazıcı H., "Yüksek firın cürufu katkılı harçların sülfat dayanıklılığının incelenmesi”, DEÜ Mühendislik Fakültesi Fen ve Mühendislik Dergisi, 8, 1, (Ocak 2006), 51.

[20]. Qasrawi, H., Shalabi, F., \& Asi, I., " Use of low $\mathrm{CaO}$ unprocessed steel slag in concrete as fine aggregate," Construction and Building Materials, 23(2), (2009), 1118-1125. 
[21]. Soroka I., “Concrete in Hot Environments”, National Building Research Institute, Faculty of Civil Engineering, Technion-Israel Institute of Technology, Haifa, Israel, 1993.

[22]. Yeau K. Y. and Kim E. K., “An Experimental Study on Corrosion Resistance of Concrete with Ground Granulated Blast-Furnace Slag”, Cement and Concrete Research, 35, (2005), 1391-1399.
[23]. Newman J., and Choo B.S., “'Advanced Concrete Technology”, Elsevier Publishing, Great Britain, 2003.

[24]. Binici H., Eken M. ve Dinçer A., "'Silis Dumanı, Uçucu Kül ve Yüksek Fırın Cürufu Katkılı Betonların Bazı Durabilite Özellikleri', Çukurova Üniversitesi Mühendislik-Mimarlık Fakültesi Dergisi, 28(1), (2013), 11-21. 